\title{
Gambaran Tingkat Kecukupan Gizi Lansia dengan Depresi di Kecamatan Pondok Jagung
}

\author{
Rosyanne Kushargina ${ }^{1}$, Alidina Nur Afifah ${ }^{2}$ \\ 1) Program Studi Sarjana Gizi, Fakultas Kedokteran dan Kesehatan, Universitas Muhammadiyah Jakarta, Indonesia \\ 2) Program Studi Pendidikan Dokter, Fakultas Kedokteran dan Kesehatan, Universitas Muhammadiyah Jakarta, Indonesia \\ *Corresponding author: rosyannekushargina@umj.ac.id
}

\begin{abstract}
Background: The population of the elderly continuously increased. This is because of the high efforts of each country to increasing the life expectancy of the population, especially in the health sector. Nutritional intake and lifestyle have influenced the physical health of the elderly. Purposes: this study aimed to analyze the nutritional adequacy of the elderly with depression in Kecamatan Pondok Jagung. Methods: This study used cross-sectional design. A total of 100 elderly were selected purposively to be respondents from Kecamatan Pondok Jagung. Data were collected by interviewer using a structured questionnaire. These data were analyzed descriptively through the univariate test. Result: The nutritional status of the subjects was mostly normal. The average of energy adequacy level was in the deficient category (male = 48.77\%; female 51.06\%). Besides fat, the average of macronutrient adequacy level were in the deficient category, consist of protein (male $=77,5 \%$; female $=79,74 \%$ ), carbohydrate (male $=$ 50,15\%; female $=50,25 \%)$, and fiber (male $=17,16 \%$; female $=17,02 \%)$. The average of micronutrient adequacy level were in the deficient category too for both male and female respondents, consist of $\mathrm{Na}$ (male $=53,68 \%$; female $=54,06 \%)$ and $\mathrm{Ca}$ (male $=30,69 \%$; female $=$ $31 \%)$. The average of fat adequacy level was in the sufficient category. Conclusion: The adequate level of energy, macronutrient besides fat, and micronutrient were in the deficient category. The average of fat adequacy level was good because that was in the sufficient category.
\end{abstract}

Keywords: depression, elderly, nutrition adequacy level, nutrients

\begin{abstract}
ABSTRAK
Latar Belakang: Populasi orang lanjut usia (lansia) terus meningkat. Peningkatan ini merupakan hasil yang baik dari berbagai upaya dari setiap negara dalam meningkatkan angka harapan hidup penduduk baik, terutama dalam bidang kesehatan. Asupan gizi dan gaya hidup memberikan pengaruh pada kesehatan fisik lansia. Tujuan: Penelitian ini bertujuan untuk menganalisis gambaran kecukupan gizi lansia dengan depresi di Kecamatan Pondok Jagung. Metode: penelitian ini menggunakan desain cross sectional. Sebanyak 100 orang lansia dengan depresi menjadi responden yang dipilih secara purposive dari Kecamatan Pondok Jagung. Data dikumpulkan dengan teknik wawancara menggunakan kuesioner terstruktur. Analisis data dilakukan secara deskriptif melalui uji univariate. Hasil: Rata-rata tingkat kecukupan energi (laki-laki $=48,77 \%$; Perempuan $=51,06 \%$ ) termasuk pada kategori kurang. Rata-rata tingkat kecukupan zat gizi makro kecuali lemak termasuk pada kategori kurang yaitu protein $($ laki-laki $=77,5 \%$; Perempuan $=79,74 \%)$, karbohidrat $($ laki-laki $=50,15 \%$; Perempuan $=$
\end{abstract}


50,25\%), dan serat (laki-laki $=17,16 \%$; Perempuan $=17,02 \%$ ). Rata-rata tingkat kecukupan lemak sudah baik yaitu termasuk pada kategori cukup (laki-laki= 56,89\%; Perempuan= $56,47 \%$ ). Tingkat kecukupan zat gizi mikro yaitu natrium (laki-laki $=53,68 \%$; Perempuan= $54,06 \%$ ) dan kalsium (laki-laki $=30,69 \%$; Perempuan $=31 \%$ ), berada pada kategori kurang. Kesimpulan: Rata-rata tingkat kecukupan energi, zat gizi makro (protein, karbohidrat, serat) dan zat gizi mikro ( $\mathrm{Na}$ dan $\mathrm{Ca}$ ) termasuk pada kategori kurang. Rata-rata tingkat kecukupan lemak sudah baik karena tergolong cukup.

Kata kunci: depresi, lansia, tingkat kecukupan gizi, zat gizi

\section{PENDAHULUAN}

Populasi orang lanjut usia (lansia) terus meningkat dan menjadi fenomena yang serius bagi seluruh negara di dunia (1). Data World Health Organization (WHO) mencatat bahwa pada tahun 2015 hingga 2050 diperkirakan jumlah populasi lansia akan meningkat sebesar $22 \%$ dibandingkan populasi lansia saat ini (2). Peningkatan ini merupakan hasil yang baik dari berbagai upaya dari setiap negara dalam meningkatkan angka harapan hidup penduduk baik, terutama dalam bidang kesehatan. Akan tetapi prediksi WHO menyebutkan pula bahwa pada tahun 2050 nanti, $80 \%$ lansia yang diperkirakan hidup tersebut merupakan lansia yang tinggal di negara berpenghasilan menengah sampai rendah (2). Membangun lansia yang memiliki pemikiran yang baik terhadap pengelolaan hari tuanya akan menjadi tantangan tersendiri bagi pemerintah sehingga tercipta kualitas lansia yang sehat dan sejahtera fisik, mental, psikososial, dan spiritual.Badan Pusat Statistik (BPS) memproyeksikan bahwa pada tahun 2045, Indonesia akan memiliki sekitar 63,31 juta penduduk lanjut usia (lansia) atau hampir mencapai $20 \%$ populasi. Bahkan, proyeksi PBB juga menyebutkan bahwa persentase lansia Indonesia akan mencapai $25 \%$ pada tahun 2050 atau sekitar 74 juta lansia (3). Salah satu fokus dari kesehatan dan kesejahteraan lansia ada pada faktor fisik dan mentalnya. Asupan gizi dan gaya hidup memberikan pengaruh pada kesehatan fisik lansia, lansia yang menjaga pola tidurnya, memperhatikan makanannya, menghindari rokok dan melakukan aktivitas fisik rutin akan lebih sehat secara fisik dibandingkan yang tidak melakukannya (4-6).

Perubahan pada lansia seperti penurunan fungsi tubuh adalah bagian dari siklus kehidupan pada lansia yang dapat mempengaruhi derajat kesehatan baik fisik maupun mental, spiritual, dan psikososial (7). Hampir $15 \%$ penduduk usia 60 tahun ke atas di dunia mengalami gangguan mental dengan mayoritas jenis gangguan tersebut adalah demensia dan depresi (1). Meta-analisis dari 74 studi didapatkan bahwa prevalensi dari kejadian depresi pada lansia di seluruh dunia menempati angka sebesar 4,7\%-16\% (8). Depresi yang dialami oleh lansia ditandai dengan perubahan suasana hati (mood). Perubahan mood tersebut meliputi perasaan sedih, merasa kesepian, merasa terbuang, mudah lelah, kehilangan nafsu makan, gangguan tidur, kehilangan minat untuk melakukan kegiatan, kehilangan tujuan hidup, kehilangan harga diri (kekhawatiran tentang menjadi beban, perasaan tidak berharga, membenci diri sendiri), penarikan sosial, memikirkan hal tentang kematian hingga memikirkan kematian untuk bunuh diri $(9,10)$. 
Tangerang Selatan merupakan kota padat penduduk yang berada di wilayah Provinsi Banten yang masuk dalam 10 besar provinsi yang memiliki jumlah lansia terbanyak di Indonesia (11). Wilayah Tangerang Selatan yang memiliki lansia terbanyak adalah di kelurahan Pondok Jagung yang berada di wilayah kerja Puskesmas Pondok Jagung (12). Oleh karena itu, penelitian ini bertujuan untuk menganalisis gambaran kecukupan gizi Lansia dengan depresi di Kecamatan Pondok Jagung.

\section{METODE}

Penelitian ini menggunakan dengan desain cross-sectional yang akan dilakukan pada bulan November 2019-Agustus 2020 bertempat di Kecamatan Pondok Jagung Tangerang Selatan. Sebanyak 100 orang Lansia menjadi responden dalam penelitian ini. Perhitungan responden menggunakan rumus Lemeshow.

Responden dalam penelitian ini adalah lansia di wilayah kerja Puskesmas Pondok Jagung yang diambil secara purposive sesuai dengan kriteria inklusi yang ditetapkan yaitu: berusia diatas 60 tahun; mengalami depresi; bersedia berpartisipasi penuh sebagai responden penelitian; tidak mengalami gangguan pendengaran; dapat berkomunikasi dengan baik; dan tidak tinggal sendiri.

Variabel yang diamati adalah karakteristik responden (Tabel 1), status gizi, konsumsi, kecukupan, dan tingkat kecukupan energi dan zat gizi. Jenis data yang dikumpulkan adalah data primer dengan teknik wawancara menggunakan kuesioner terstruktur. Data berat badan dan tinggi badan didapat dari pengukuran secara langsung. Dilakukan pengukuran lingkar betis untuk estimasi tinggi badan Lansia yang kesulitan berdiri (13). Status gizi ditentukan menggunakan Indeks Massa Tubuh (IMT) dengan acuan standar klasifikasi IMT untuk Indonesia (14).

Kuesioner diuji validitas dan reliabilitasnya dengan alfa cronbach. Kuesioner terdiri atas tiga bagian yaitu pertanyaan mengenai karakteristik responden, kuesioner Geriatric Depression Scale (GDS)(15) dan kuesioner Food Record $3 x 24$ jam (2 hari kerja dan 1 hari libur).

Kuesioner GDS berisi 15 pertanyaan yang ditanyakan pada setiap responden dengan jawaban ya atau tidak, dengan maksimal skor 15. Terdapat empat kategori depresi yang digunakan yaitu normal (skor 0 ), depresi ringan ( skor 1-4), depresi sedang (skor 5-9) dan depresi berat (skor 10-15) (15).

Kuesioner food record untuk data konsumsi diisi oleh pendamping atau keluarga yang tinggal bersama responden. Kecukupan gizi diketahui dengan membandingkan konsumsi dengan kecukupan responden. Kategori kecukupan gizi untuk energi dan zat gizi makro (protein dan karbohidrat) terbagi menjadi tiga kategori yaitu kurang, baik dan lebih, sedangkan untuk lemak terbagi ke dalam dua kategori yaitu cukup dan lebih (16). Kategori untuk zat gizi mikro (Na dan Ca) dan serat terbagi dua yaitu kurang dan cukup (13).

Tingkat kecukupan energi dan zat gizi diketahui dengan membandingkan antara konsumsi dan kecukupan responden. Kecukupan energi dan zat gizi ditentukan menggunakan Angka Kecukupan Gizi (AKG) sesuai rentang usia dengan koreksi berat badan aktual responden. Acuan untuk perhitungan kecukupan energi dan zat gizi menggunakan standar AKG tahun 2019 (17).

Penelitian ini telah mendapatkan persetujuan dari Komite Etik Penelitian Kesehatan (KEPK) Fakultas Kedokteran dan Kesehatan, Universitas Muhammadiyah Jakarta No. 186/PE/KE/FKK-UMJ/XI/2019. 


\section{HASIL}

Karakteristik responden dapat dilihat pada Tabel 1. Responden terdiri dari 49 orang laki-laki dan 51 orang perempuan. Klasifikasi berdasarkan jenis kelamin bertujuan untuk membandingkan variablevariabel yang diamati antara laki-laki dan perempuan. Perbedaan metabolism tubuh antara laki-laki dan perempuan dapat menyebabkan perbedaan nilai pada variabel yang diamati tersebut.

Tabel 1. Karakteristik Responden Penelitian

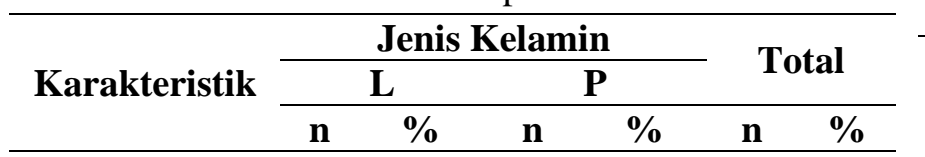

\section{Umur}

$\begin{array}{lcccccc}\text { Elderly } & 42 & 48,84 & 44 & 51,16 & 86 & 100 \\ \text { Old } & 7 & 50,00 & 7 & 50,00 & 14 & 100\end{array}$

Status Pernikahan

$\begin{array}{lcccccc}\text { Lengkap } & 46 & 56,10 & 36 & 43,90 & 82 & 100 \\ \text { Tidak Lengkap } & 3 & 16,67 & 15 & 83,33 & 18 & 100 \\ \text { (Janda/Duda) } & & & & & & \end{array}$

Penghasilan

$\begin{array}{lcccccc}1 & 23 & 48,94 & 24 & 51,06 & 47 & 100 \\ 2 & 12 & 44,44 & 15 & 55,56 & 27 & 100 \\ 3 & 7 & 53,85 & 6 & 46,15 & 13 & 100 \\ 4 & 7 & 53,85 & 6 & 46,15 & 13 & 100\end{array}$

Pendidikan

$\begin{array}{lllllll}\text { Tidak Sekolah } & 2 & 40,00 & 3 & 60,00 & 5 & 100\end{array}$ $\begin{array}{lllllll}\text { SD } & 32 & 48,48 & 34 & 51,52 & 66 & 100\end{array}$ $\begin{array}{lllllll}\text { SMP } & 10 & 50,00 & 10 & 50,00 & 20 & 100\end{array}$ $\begin{array}{lrrrrrr}\text { SMA } & 5 & 55,56 & 4 & 44,44 & 9 & 100\end{array}$ Ket: L=Laki-laki; P=Perempuan, Penghasilan 1:Kurang dari 1.000.000; 2:1.100.000-1.500.000; 3:1.600.000-2.000.000; 4:Lebih dari 2.100.000

Sebagian besar responden berada pada kategori elderly dengan rentang usia 60-74 tahun baik untuk responden laki-laki $(85,71 \%)$ maupun perempuan $(14,29 \%)$. Responden laki-laki masih berada dalam pernikahan yang lengkap, yaitu masih didampingi istri $(56,10 \%)$. Berbeda dengan laki-laki, responden perempuan Sebagian besar menyandang status janda $(83,33 \%)$.

Penghasilan responden dominan berada pada kisaran kurang dari Rp.1.000.000,- untuk responden laki-laki
$(67,65 \%)$ dan perempuan (32,35\%). Sebagian besar responden laki-laki hanya bersekolah sampai tingkat Sekolah Dasar (SD) $(43 \%)$. Sebanyak $60 \%$ responden perempuan tidak pernah bersekolah. Seluruh responden laki-laki memiliki status gizi normal (Tabel 2) yaitu sebanyak $51,04 \%$.

Tabel 2. Status Gizi Responden berdasarkan Jenis Kelamin

\begin{tabular}{lcccccc}
\hline \multirow{2}{*}{$\begin{array}{l}\text { Status } \\
\text { Gizi }\end{array}$} & \multicolumn{4}{c}{ Jenis Kelamin } & \multirow{2}{*}{ Total } \\
\cline { 2 - 6 } & Laki-Laki & \multicolumn{2}{c}{ Perempuan } & \multicolumn{1}{c}{} \\
\cline { 2 - 6 } & $\mathbf{n}$ & $\mathbf{\%}$ & $\mathbf{n}$ & $\mathbf{\%}$ & $\mathbf{n}$ & $\mathbf{\%}$ \\
\hline Kurus & 0 & 0 & 2 & 100 & 2 & 100 \\
Normal & 49 & 51,04 & 47 & 48,96 & 96 & 100 \\
Obesitas & 0 & 0 & 2 & 100 & 2 & 100 \\
\hline
\end{tabular}

Sebagian besar responden perempuan juga memiliki status gizi normal (48,96\%) meskipun terdapat juga responden perempuan dengan status gizi kurus dan obesitas. Status depresi responden dapat dilihat pada Tabel 3. Sebagian besar responden mengalami depresi ringan baik laki-laki $(56,10 \%)$ maupun perempuan $(43,90 \%)$.

Tabel 3.Status Depresi Responden berdasarkan Jenis Kelamin

\begin{tabular}{|c|c|c|c|c|c|c|}
\hline \multirow{3}{*}{$\begin{array}{l}\text { Status } \\
\text { Depresi }\end{array}$} & \multicolumn{4}{|c|}{ Jenis Kelamin } & \multirow{2}{*}{\multicolumn{2}{|c|}{ Total }} \\
\hline & \multicolumn{2}{|c|}{ Laki-Laki } & \multicolumn{2}{|c|}{$\begin{array}{c}\text { Perempua } \\
\text { n }\end{array}$} & & \\
\hline & n & $\%$ & n & $\%$ & n & $\%$ \\
\hline Rin & 46 & 56,10 & 36 & 43,90 & 82 & 100 \\
\hline Sedang & 3 & 16,67 & 15 & 83,33 & 18 & 100 \\
\hline
\end{tabular}

Rata-rata tingkat kecukupan energi dan karbohidrat (Tabel 4) responden baik laki-laki $(48,77 \%)$ maupun perempuan $(51,06 \%)$ berada pada kategori kurang. Rata-rata tingkat kecukupan protein responden berada pada kategori kurang yaitu 77,50\% untuk laki-laki dan 79,74\% untuk perempuan. Rata-rata tingkat kecukupan kecukupan lemak sudah baik 
yaitu termasuk pada kategori cukup. Ratarata tingkat kecukupan serat, natrium dan kalsium berada pada kategori kurang, baik untuk responden laki-laki maupun perempuan.

\section{PEMBAHASAN}

Terdapat beberapa kelompok rawan gizi. Salah satunya adalah lansia. Lansia adalah seseorang yang berusia 60 tahun ke atas baik pria maupun wanita, yang masih aktif beraktivitas dan bekerja ataupun mereka yang tidak berdaya untuk mencari nafkah sendiri sehingga bergantung kepada orang lain untuk menghidupi dirinya (18). Organisasi Kesehatan Dunia (WHO) membagi lansia menjadi 4 golongan. Golongan pertama disebut sebagai usia pertengahan (middle age) yaitu lansia yang berusia 45 - 59 tahun. Golongan kedua adalah lanjut usia (elderly) yaitu lansia yang berusia $60-74$ tahun. Lanjut usia tua (old) merupakan golongan ketiga. Lansia yang masuk golongan ini adalah yang berusia 75 - 90 tahun. Golongan yang terakhir adalah usia sangat tua (very old) yang berusia diatas 90 tahun (19).
Proses penuaan merupakan suatu akumulasi perubahan yang kompleks karena menyebabkan terjadinya perubahan multidimensional. Dilihat dari segi biologis, penuaan merupakan proses turunnya daya tahan tubuh akibat perubahan dalam struktur dan fungsi sel, jaringan, serta sistem organ sehingga terjadi kemunduran fisiologis, psikologis. Kemunduran fisiologis adalah perubahanperubahan tubuh yang terjadi pada tubuh dalam proses menua, seperti rambut beruban dan berkurang, kulit kering dan keriput, detak jantung menjadi kurang stabil, hingga gangguan peredaran darah dan pencernaan $(20,21)$.

Sebagian besar responden penelitian ini hanya berpendidikan SD bahkan tidak sama sekali bersekolah. Penelitian terdahulu membuktikan bahwa tingkat pendidikan berpengaruh signifikan terhadap tingkat pendapatan individu, dimana semakin tinggi tingkat pendidikan, tingkat pendapatan juga akan meningkat (22). Hasil penelitian tersebut sejalan dengan penelitian ini, di mana sebagian besar responden memiliki penghasilan kurang dari Rp. 1.000.000.

Tabel 4. Rata-rata Tingkat Kecukupan Gizi Responden berdasarkan Jenis Kelamin

\begin{tabular}{lcccccccc}
\hline \multirow{2}{*}{ Zat Gizi } & \multicolumn{2}{c}{ Kecukupan } & \multicolumn{2}{c}{ Konsumsi } & \multicolumn{3}{c}{ Tingkat Kecukupan (\%) } \\
\cline { 2 - 9 } & $\mathbf{L}$ & $\mathbf{P}$ & $\mathbf{L}$ & $\mathbf{P}$ & $\mathbf{L}$ & $\begin{array}{c}\text { Kategori } \\
\text { Kecukupan }\end{array}$ & $\mathbf{P}$ & $\begin{array}{c}\text { Kategori } \\
\text { Kecukupan }\end{array}$ \\
\hline Energi (kkal) & 3006 & 2992 & 1452 & 1510 & 48,77 & Kurang & 51,06 & Kurang \\
\hline Protein (gram) & 102,8 & 102,41 & 79,56 & 81,47 & 77,5 & Kurang & 79,74 & Kurang \\
\hline lemak (gram) & 84,28 & 83,94 & 47,4 & 46,92 & 56,89 & Cukup & 56,47 & Cukup \\
\hline KH (gram) & 462,11 & 459,87 & 227,52 & 226,85 & 50,15 & Kurang & 50,25 & Kurang \\
\hline Serat (gram) & 41,96 & 41,78 & 7,12 & 7,04 & 17,16 & Kurang & 17,02 & Kurang \\
\hline $\mathrm{Na}(\mathrm{mg})$ & 2042,99 & 2057,86 & 1082,79 & 1098,57 & 53,68 & Kurang & 54,06 & Kurang \\
\hline $\mathrm{Ca}(\mathrm{mg})$ & 1992,45 & 1992,45 & 611,55 & 617,58 & 30,69 & Kurang & 31,00 & Kurang \\
\hline
\end{tabular}

Ket: L=Laki-laki; P=Perempuan 
Status gizi merupakan kondisi yang terjadi pada tubuh sebagai hasil dari konsumsi. Banyak faktor yang mempengaruhi status gizi. Banyak faktor yang mempengaruhi status gizi. Penilaian status gizi dapat dilakukan secara langsung dan tidak langsung. Penilaian secara langsung dapat dibagi menjadi empat, yaitu antropometri, klinis, biokimia, dan biofisik sedangkan secara tidak langsung dibagi menjadi tiga, yaitu survei konsumsi pangan, data statistika vital dan faktor ekologi (23). Status gizi sebagian besar responden perempuan dan semua responden laki-laki termasuk dalam kategori normal. Hasil penelitian ini berbeda dengan penelitian sebelumnya (24). Penelitian tersebut menyatakan bahwa lansia yang mengalami depresi berpeluang 9,75 kali lebih besar untuk mengalami malnutrisi dibandingkan lansia dengan tidak depresi $[\mathrm{OR}=9,75,95 \%$ $\mathrm{CI}=1,63(1,45-1,81)](24)$. Data berat badan pada penelitian tersebut diambil dua minggu pasca puasa Ramadhan, sehingga hasil pengukuran berat badan kemungkinan dipengaruhi kondisi puasa. Hal ini lah yang diduga menyebabkan perbedaan hasil penelitian ini dengan penelitian terdahulu.

Depresi pada lansia dapat disebabkan oleh banyak hal yaitu penyakit terkait seperti hipertensi, perubahan fisik, perubahan situasi (masa pensiun, relokasi tempat tinggal) dan kurangnya dukungan keluarga. Sekitar $80 \%$ dari lansia memiliki setidaknya satu kondisi kesehatan kronis dan 50\% memiliki dua atau lebih penyakit kronis. Depresi lebih sering terjadi pada seseorang yang memiliki penyakit seperti penyakit jantung dan kanker atau yang fungsinya menjadi terbatas (stroke, alzheimer, parkinson, dan arthritis) (25).

Responden dominan memiliki status gizi normal. Rata-rata tingkat Kecukupan energi dan zat gizi responden berada pada kategori kurang, kecuali untuk lemak yang berada pada kategori cukup. Proses menua sangat dipengaruhi oleh asupan makanan. Hal ini disebabkan karena aktivitas sel atau metabolisme dalam tubuh membutuhkan energi dan zat gizi yang cukup. Perubahan biologi yang terjadi pada lansia merupakan merupakan faktor internal yang dapat mempengaruhi status gizi (21). Kesehatan pada lansia juga mempengaruhi kecukupan energi dan zat gizinya (26). Akibatnya, banyak lansia tidak mencapai asupan gizi yang cukup untuk mendukung kebutuhan minimalnya dan berisiko malnutrisi (27).

Meskipun status gizi responden dalam keadaan baik, asupan harus dijaga agar status gizi tetap dalam kondisi normal. Malnutrisi secara signifikan lebih tinggi pada populasi lansia bahkan meskipun lansia tersebut memiliki indeks massa tubuh (IMT) normal. Ini terjadi karena perubahan komposisi tubuh dengan peningkatan progresif lemak dan penurunan massa tubuh tanpa lemak seiring bertambahnya usia.

Pada lansia, malnutrisi memiliki dampak buruk yang merugikan tentang kesehatan umum. Malnutrisi mengakibatkan kelelahan, kelemahan, aktivitas berkurang, dan munculnya berbagai penyakit. Malnutrisi juga dianggap sebagai faktor risiko terjadinya morbiditas dan mortalitas pada lansia (20).

\section{SIMPULAN}

Rata-rata tingkat kecukupan energi, zat gizi makro (protein dan karbohidrat), zat gizi mikro (Na dan $\mathrm{Ca}$ ) dan serat termasuk pada kategori kurang. Status gizi responden sebagian besar adalah normal. Perubahan fisiologis yang terjadi pada lansia akan berpengaruh terhadap seluruh aspek kehidupan, termasuk kesehatan. Oleh karena itu penting untuk selalu menjaga 
asupan energi dan zat gizi untuk menjaga status gizi lansia tetap baik.

\section{UCAPAN TERIMA KASIH}

Penulis mengucapkan terima kasih kepada Puskesmas Kecamatan Pondok Jagung yang telah membantu pelaksanaan kegiatan penelitian, FKK UMJ yang telah memberikan dana penelitian, dan semua pihak yang telah membantu dalam penyusunan artikel ini.

\section{KONFLIK KEPENTINGAN}

Penulis tidak memiliki konflik kepentingan terhadap organisasi manapun.

\section{REFERENSI}

1. Buvneshkumar M, John KR, Logaraj M. A Study on Prevalence of Depression and Associated Risk Factors among Elderly in a Rural Block of Tamil Nadu. Indian J Public Health. 2018;2(62):89-94.

2. WHO. Ageing and health [Internet]. 2018. Available from: https://www.who.int/newsroom/fact-sheets/detail/ageing-andhealth

3. BPS. Statistik Penduduk Lanjut Usia 2020 [Internet]. 2020. Available from: https://www.bps.go.id

4. Leslie W, Hankey C. Aging, Nutritional Status and Health. Heal care J. 2015;3(3):648-58.

5. Woo J, Ho SC, Yu ALM. Lifestyle Factors and Health Outcomes in Elderly Hong Kong Chinese Aged 70 Years and Over. Gerontology [Internet]. 2002;48(4):234-40. Available from: https://www.karger.com/Article/Ful 1Text/58356

6. Poda GG, Hsu C-Y, Rau H-H, Chao JC-J. Impact of socio-demographic factors, lifestyle and health status on nutritional status among the elderly in Taiwan. Nutr Res Pract. 2019;13(3):222-9.

7. Prabhaswari L, Ariastuti NLP. Gambaran Kejadian Depresi pada Lanjut Usia di Wilayah Kerja Puskesmas Petang 1 Kabupaten Badung Bali 2015. Intisari Sains Medias. 2015;7:47-52.

8. Barua A, Gosh MK, Kar N, Basilio MA. Prevalence of depressive disorders in the elderly. Ann Saudi Med. 2011;31(6):620-4.

9. Fadhillah W, Rachmawati IN. Tingkat Depresi pada Lansia yang Tinggal dengan Keluarga. Library of Indonesia University. Universitas Indonesia; 2013.

10. Buvneshkumar M, John KR, Logaraj M. A study on prevalence of depression and associated risk factors among elderly in a rural block of Tamil Nadu. Indian J Public Health. 2018;62(2):89-94.

11. Kementerian Kesehatan Republik Indonesia. Profil Kesehatan Indonesia 2017. Jakarta; 2018.

12. Dinas Kesehatan Tangerang Selatan. Laporan Kinerja Instansi Pemerintah (LKIP) $2017 \quad$ [Internet]. 2018. Available from: https://dinkes.tangerangselatankota. go.id/uploads/lkip/8.pdf

13. Gibson RS. Principles of Nutritional Assessment - Rosalind S. Gibson Google Books. Oxford University Press. 2005.

14. Kementerian Kesehatan. Pedoman Gizi Seimbang. Peraturan Menteri Kesehatan Republik Indonesia Nomor 41 tentang Pedoman Gizi Seimbang 2014.

15. Greenberg SA. The Geriatric 
Depression Scale (GDS). Try This:

Best Practices in NUrsing Care to Older Adulths. The Hartford Institute for Geriatric Nursing: New York University. 2012.

16. Widajanti L. Survei Konsumsi Gizi. Semarang: Badan Penerbit Universitas Diponegoro; 2009.

17. Kementerian Kesehatan Republik Indonesia. Peraturan Menteri Kesehatan Republik Indonesia Nomor 28 Tahun 2019 tentang Angka Kecukupan Gizi yang Dianjurkan Untuk Masyarakat Indonesia. Jakarta; 2019.

18. Supardi DI. Pengaruh Terapi Warna Merah terhadap Daya Ingat Pada Lansia di Unit Rehabilitasi Sosial Dewanata Cilacap [Internet]. Universitas Jenderal Soedirman; 2012. Available from: https://d3.spmb.unsoed.ac.id/index. php?r=artikelilmiah/view\&id $=4712$

19. Brown JE. Nutrition Through the Life Cycle, 4th Ed. Fluoride. 2011.

20. JafariNasabian P, Inglis JE, Reilly W, Kelly OJ, Ilich JZ. Aging human body: Changes in bone, muscle and body fat with consequent changes in nutrient intake. J Endocrinol. 2017;234(1):R37-51.

21. Frenzel A, Binder $\mathrm{H}$, Walter $\mathrm{N}$, Wirkner K, Loeffler M, LoefflerWirth $\mathrm{H}$. The aging human body shape. npj Aging Mech Dis [Internet]. 2020 Dec 24;6(1):5. Available from: http://www.nature.com/articles/s415 14-020-0043-9

22. Julianto D, Utari PA. Analisa pengaruh tingkat pendidikan terhadap pendapatan individu di Sumatera Barat. Ikra-Ith Ekon. 2019;2(2):122-31.
23. Muhammad I, Desty Ervira P. Penilaian Status Gizi: ADCD. Penebit Salemba Medika; 2018.

24. Putri HR, Nindya TS. Hubungan Kecenderungan Depresi dengan Status Gizi pada Lansia di UPTD Griya Werdha Surabaya. Media Gizi Indones. 2019;14(1).

25. National Institute of Mental Health. Depression Basics. National Institutes of Health. 2016.

26. Fatma. Gizi Usia Lanjut. Jakarta: Penerbit Erlangga; 2010.

27. Nieuwenhuizen WF, Weenen $\mathrm{H}$, Rigby P, Hetherington MM. Older adults and patients in need of nutritional support: Review of current treatment options and factors influencing nutritional intake. Clin Nutr [Internet]. 2010 Apr;29(2):160-9. Available from: https://linkinghub.elsevier.com/retri eve/pii/S0261561409001836 